AC 2011-2761: RE-ENGINEERING THE CAPSTONE: MELDING AN INDUSTRY ORIENTED FRAMEWORK AND THE BOK2

John V Tocco, Lawrence Technological University

Donald D. Carpenter, Lawrence Technological University

Dr. Donald Carpenter is an Associate Professor of Civil Engineering and the Director of Assessment at Lawrence Technological University. Prior to being Director of Assessment, Dr. Carpenter was the Founding Director for the Center of Teaching \& Learning at Lawrence Tech where he was responsible for conducting faculty development programs. In addition, Dr. Carpenter actively conducts educational and pedagogical research on teamwork, leadership, and ethical development and is Kern Fellow for Entrepreneurial Education. 


\title{
Re-Engineering the Capstone: Melding an Industry Oriented Framework and the BOK2
}

\begin{abstract}
The Department of Civil Engineering at Lawrence Technological University requires senior-level students to participate in a two-term capstone sequence in their senior year. As part of faculty's commitment to continuous improvement, discussions were often held regarding revising the sequence to provide students with a more realistic and professionally relevant experience. The impetus to effect substantive changes arose in spring 2008 when the department adopted the program outcomes set forth in the Civil Engineering Body of Knowledge Second Edition (BOK2), as promulgated by the American Society of Civil Engineers. During initial discussions, faculty recognized that the program outcomes dovetailed perfectly with the goal of revitalizing the capstone. This paper discusses how the participation of industry practitioners, and adopting the BOK2 outcomes, were applied to the capstone content, resulting in a much more interesting, professional and vibrant sequence. Examples of resultant positive changes include clearer student deliverables and evaluator expectations, a more pragmatic approach to project scope and documentation, and meaningful student/practitioner interaction at important project junctures.
\end{abstract}

\section{Introduction}

This manuscript focuses on re-engineering the major design and project management experience, or capstone sequence, for the Department of Civil Engineering (Department) at Lawrence Technological University occurs over two terms:

ECE4021 CE Design Project 1 (CE Project 1), a one-credit course offered in the fall, and ECE4033 CE Design Project 2 (CE Project 2), a three-credit course offered in the spring.

Students form their own teams of three to five members and develop a project where they generate a conceptual design and project management plan. The capstone represents the culmination of the students' undergraduate education, providing them an opportunity to integrate various curricular components in preparation for careers as civil engineers.

Neither course has an instructor in the traditional sense of the word; in other words, no single individual is the sole purveyor of knowledge. Instead, a course coordinator, serving as the instructor of record, facilitates the creation and dissemination of the syllabi, manages deliverable dates, and generally serves an administrative function, including processing grades. Each course has a project initiation meeting at the start of the term and various interactions with mentors (as discussed in subsequent sections). Also, CE Project 1 includes a few one-hour professional skills review seminars, such as technical writing and presentation best practices.

During previous continuous improvement reviews, faculty considered simplifying the process by requiring all teams to generate a proposal based on a common project, thus normalizing the constraints. However, students have repeatedly stated that they appreciate the opportunity to research and select the projects and locations of their choice. Moreover, other institutions have demonstrated that allowing a diversity of projects is a factor in increasing student motivation and 
learning ${ }^{1}$. Table 1 lists the projects from the 2009-2010 capstone sequence, and illustrates the wide range of choices the students make. Students are also required to determine a team name and logo which represents their "firm's" identity.

Table 1 2009-2010 Capstone Projects

\begin{tabular}{|c|c|c|c|}
\hline Team Name & $\begin{array}{c}\text { Number of } \\
\text { Students }\end{array}$ & Project Name & Project Description \\
\hline KGML Group & 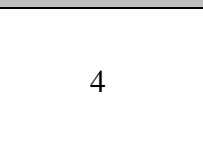 & Atwater Medical Facility & $\begin{array}{l}48,000 \text { s.f. medical office building in } \\
\text { the Eastern Market district in Detroit; } \\
\text { includes a medical clinic, daycare, } \\
\text { pharmacy and rentable office space }\end{array}$ \\
\hline WTLL & 4 & $\begin{array}{c}\text { Carus Lake Sustainable } \\
\text { Development }\end{array}$ & $\begin{array}{l}\text { Development is adjacent to a restored } \\
\text { conservation area; includes a nature } \\
\text { center, farmers' market, community } \\
\text { gardens and new road network }\end{array}$ \\
\hline $\begin{array}{l}\text { High Top Civil } \\
\text { Consultants }\end{array}$ & 4 & Highway Haven & $\begin{array}{l}\text { Rest area and welcome center on I-75; } \\
\text { access is allowed from both sides of } \\
\text { freeway; includes space for fast food } \\
\text { restaurants and retail shops }\end{array}$ \\
\hline Premier Engineers & 4 & Huron Township Civic Center & $\begin{array}{l}73,000 \text { s.f. recreational facility that } \\
\text { features a gymnasium, swimming } \\
\text { pool, auditorium and retail space; } \\
\text { access roads redesigned to include a } \\
\text { roundabout }\end{array}$ \\
\hline MC Development & 5 & Open Air Shopping Mall & $\begin{array}{l}\text { Low impact outdoor shopping mall in } \\
\text { Canton; includes green roofs, a } \\
\text { redesign of the existing access road, } \\
\text { and a sustainable stormwater system }\end{array}$ \\
\hline IAW Engineering & 3 & $\begin{array}{c}\text { Stony Creek Metro Park Nature } \\
\text { Center }\end{array}$ & $\begin{array}{l}10,000 \text { s.f. educational nature center in } \\
\text { a state park; includes classrooms, } \\
\text { conference rooms, exhibition areas } \\
\text { and office space }\end{array}$ \\
\hline EEE Consultants & 3 & Volunteer Park Redevelopment & $\begin{array}{l}\text { Upgrading and expansion of an } \\
\text { existing 130-acre park in South Lyon; } \\
\text { adding baseball, soccer and softball } \\
\text { fields, and bike and hiking paths; } \\
\text { includes redesign of adjacent roads }\end{array}$ \\
\hline
\end{tabular}

This paper seeks to describe how a capstone sequence was improved by infusing industry participation and the civil engineering body of knowledge. Increasing industry participation in the capstone process has been successful in other civil engineering curriculum, but admittedly is more work for the department and the students ${ }^{1,2}$. However, logistical challenges are outweighed by the benefits, which include program improvement ${ }^{1,3,4}$, determining gaps in student understanding of technical knowledge ${ }^{2,3,5}$, student engagement ${ }^{2,4,6,7}$, student motivation ${ }^{1,5,7}$, job placement $^{7}$, and addressing non-technical outcomes ${ }^{5,7,8,9,10}$. Preliminary results indicate that Lawrence Tech is experiencing many of the previously reported benefits, suggesting a model that could be adopted by other institutions. 


\section{Adoption of the BOK2}

The Department's program outcomes initially tracked those set forth in the ABET requirements, with some minor differences. In 2008, in accordance with its assessment program, the Department prepared to review its outcomes to determine if revisions or additions were preferred or required. Coincidentally, the American Society of Civil Engineers (ASCE) had recently published the Civil Engineering Body of Knowledge for the $21^{\text {st }}$ Century, Second Edition $(B O K 2)^{11}$. Based on the suggestion from a Civil Engineering Advisory Board member who was a member of the ASCE BOK2 Committee, the Department Assessment Coordinator presented the BOK2 to faculty for its consideration and eventual adoption in 2008.

The main purpose of the BOK2 was to clearly set forth the twenty-four outcomes that a civil engineer should be capable of prior to entering the professional practice of civil engineering ${ }^{11}$. The outcomes are placed into one of three categories: foundational, technical and professional. The BOK2 outcomes are also written to reflect preparation as a continuum ${ }^{11,12}$, distinguishing between Bloom's level of cognitive achievement ${ }^{13}$ for baccalaureate level work, to postbaccalaureate, and finally to pre-licensure experience. Therefore, the BOK2 describes what students should achieve by the time they graduate, along with the additional preparation required for them to achieve licensure and practice professionally.

Adopting the BOK2 required the review of all civil engineering courses to determine if their content was sufficient to meet the new outcomes. Moreover, their respective course objectives were painstakingly revised as necessary. The capstone sequence was part of this process, and in sections III A. and III B. below the applicable program outcomes are mapped to specific objectives for each course. The nature of a capstone-a culmination of four years of educational experience-dictates that it should address a wide range of outcomes. This comprehensive coverage is consistent with other civil engineering programs who have also attempted to map their curriculum to the $\mathrm{BOK}^{8,9,10}$.

As demonstrated in Table 2 below, seventeen of the twenty-four BOK2 program outcomes are addressed in the capstone sequence, including many of the challenging or "red" outcomes ${ }^{8,14}$. The "red" designation are BOK2 outcomes identified by the ASCE as sufficiently challenging to devote adequate coverage to, based on a survey of ten civil engineering programs. ${ }^{14}$ Challenging outcomes covered by the Lawrence Tech capstone sequence include \#4 Social Sciences, \#10 Sustainability, \#12 Risk and Uncertainty, \#17 Public Policy, \#18 Business and Public Administration, and \#20 Leadership. 
Table 2: Program Outcomes Addressed by the Capstone Sequence

\begin{tabular}{|c|c|}
\hline & Foundational Outcomes \\
\hline \multirow[t]{2}{*}{$\begin{array}{l}4 \\
\text { Social Sciences }\end{array}$} & $\begin{array}{c}\text { Demonstrate the incorporation of social sciences knowledge into the professional practice of } \\
\text { engineering. }\end{array}$ \\
\hline & $\begin{array}{l}\text { Technical Outcomes } \\
\end{array}$ \\
\hline $\begin{array}{c}5 \\
\text { Materials Science }\end{array}$ & Use knowledge of materials science to solve problems appropriate to civil engineering. \\
\hline $\begin{array}{c}6 \\
\text { Mechanics }\end{array}$ & Analyze and solve problems in solid and fluid mechanics. \\
\hline $\begin{array}{c}\text { 8 } \\
\text { Problem } \\
\text { Recognition } \\
\text { and Solving }\end{array}$ & $\begin{array}{c}\text { Develop problem statements and solve both well-defined and open-ended civil engineering problems } \\
\text { by selecting and applying appropriate techniques and tools. }\end{array}$ \\
\hline $\begin{array}{c}9 \\
\text { Design }\end{array}$ & $\begin{array}{l}\text { Design a system or process to meet desired needs within such realistic constraints as economic, } \\
\text { environmental, social, political, ethical, health and safety, constructability and sustainability. }\end{array}$ \\
\hline $\begin{array}{l}10 \\
\text { Sustainability }\end{array}$ & $\begin{array}{l}\text { Apply the principles of sustainability to the design of traditional and emergent engineering systems } \\
\text { and explain how civil engineers should strive to comply with the principles of sustainable } \\
\text { development in the performance of their professional duties. }\end{array}$ \\
\hline $\begin{array}{c}12 \\
\text { Risk and } \\
\text { Uncertainty }\end{array}$ & Apply the principles of probability and statistics and solve problems containing uncertainty. \\
\hline $\begin{array}{c}13 \\
\text { Project } \\
\text { Management }\end{array}$ & $\begin{array}{l}\text { Analyze a proposed project and formulate documents for incorporation into the project management } \\
\text { plan. }\end{array}$ \\
\hline $\begin{array}{c}14 \\
\text { Breadth in Civil } \\
\text { Engineering Areas }\end{array}$ & $\begin{array}{c}\text { Analyze and solve well-defined engineering problems in at least four technical areas appropriate to } \\
\text { civil engineering. }\end{array}$ \\
\hline \multirow[t]{2}{*}{$\begin{array}{c}15 \\
\text { Technical } \\
\text { Specialization }\end{array}$} & $\begin{array}{c}\text { Apply specialized tools or technologies to solve problems in traditional or emerging specialized } \\
\text { technical areas of civil engineering. }\end{array}$ \\
\hline & Professional Outcomes \\
\hline $\begin{array}{c}16 \\
\text { Communication }\end{array}$ & $\begin{array}{l}\text { Plan, compose and integrate the verbal, written, virtual and graphical communication of a project to } \\
\text { technical and non-technical audiences. }\end{array}$ \\
\hline $\begin{array}{c}17 \\
\text { Public Policy } \\
\end{array}$ & Discuss and explain key concepts and processes involved in public policy. \\
\hline $\begin{array}{l}18 \\
\text { Business } \\
\text { and Public } \\
\text { Administration }\end{array}$ & Explain key concepts and processes used in business and public administration. \\
\hline $\begin{array}{c}20 \\
\text { Leadership }\end{array}$ & $\begin{array}{c}\text { Explain leadership principles and attitudes and apply those principles and attitudes when making } \\
\text { decisions and directing the efforts of a small group. }\end{array}$ \\
\hline $\begin{array}{c}21 \\
\text { Teamwork }\end{array}$ & $\begin{array}{l}\text { Function effectively as a member of an intra-disciplinary team and evaluate the performance of the } \\
\text { team and individual team members. }\end{array}$ \\
\hline $\begin{array}{c}22 \\
\text { Attitudes } \\
\end{array}$ & Explain attitudes supportive of the professional practice of civil engineering. \\
\hline $\begin{array}{c}23 \\
\text { Lifelong Learning }\end{array}$ & $\begin{array}{c}\text { Demonstrate the ability for self-directed learning and identify additional knowledge, skills and } \\
\text { attitudes appropriate for continued professional practice. }\end{array}$ \\
\hline
\end{tabular}




\section{Evolution of the Capstone Sequence}

\section{A. CE Project 1}

The overall goals for CE Project 1 are the initiation and planning for a proposed project. Students establish objectives, analyze alternative solutions and generate deliverables in the context of real-world constraints. Each project must involve a minimum of four civil engineering subdisciplines, including construction engineering.

Some of the tasks students perform in the first course of the capstone sequence include:

- forming a project team by self-selecting members;

- identifying and evaluating alternative projects and sites;

- analyzing relevant background data and potential constraints, such as soil composition, zoning and code requirements, sustainability issues, etc.;

- selecting a project and developing a scope of work; and

- commencing initial design and project management tasks.

Table 3 lists the course objectives for CE Project 1, along with their program outcome correlates.

\section{Table 3: CE Project 1 Course Objectives}

\begin{tabular}{|c|c|c|}
\hline NO. & OBJECTIVE & OUTCOMES \\
\hline 1. & $\begin{array}{l}\text { Form an intradisciplinary project team, choose a leader, and assign } \\
\text { responsibilities for at least four subdisciplines in order to master } \\
\text { multiple portions of the technical breadth and specialization outcomes } \\
\text { required to function as competent civil engineers. }\end{array}$ & $\begin{array}{l}\text { 14. Breadth } \\
\text { 15. Technical Specialization } \\
\text { 20. Leadership } \\
\text { 21. Teamwork } \\
\text { 22. Attitudes }\end{array}$ \\
\hline 2. & $\begin{array}{l}\text { Based on the design-build integrative project delivery method, generate } \\
\text { a proposal describing a project that addresses real-world constraints and } \\
\text { issues, including sustainability and other sociopolitical considerations. }\end{array}$ & $\begin{array}{l}\text { 3. Social Sciences } \\
\text { 8. Problem Solving } \\
\text { 10. Sustainability } \\
\text { 12. Risk \& Uncertainty } \\
\text { 17. Public Policy } \\
\text { 18. Business \& Public } \\
\quad \text { Administration }\end{array}$ \\
\hline 3. & $\begin{array}{l}\text { As a component of the initiation and planning process groups, create an } \\
\text { initial project management plan that includes appropriate project } \\
\text { management processes, such as scope, cost and communication } \\
\text { management plans. }\end{array}$ & 13. Project Management \\
\hline 4. & $\begin{array}{l}\text { Investigate and review industry design and construction codes, as well as } \\
\text { applicable local ordinances and state and federal laws. }\end{array}$ & $\begin{array}{l}\text { 9. Design } \\
\text { 10. Sustainability } \\
\text { 17. Public Policy } \\
\text { 18. Business \& Public } \\
\text { Administration } \\
\text { 23. Lifelong Learning }\end{array}$ \\
\hline 5. & $\begin{array}{l}\text { Utilize civil engineering knowledge and skills to generate and analyze } \\
\text { preliminary design alternatives for components of each subdiscipline, } \\
\text { and choose the most appropriate alternatives for the project. }\end{array}$ & $\begin{array}{l}\text { 5. Material Science } \\
\text { 6. Mechanics } \\
\text { 8. Problem Solving } \\
\text { 9. Design } \\
\text { 10. Sustainability } \\
\text { 12. Risk \& Uncertainty }\end{array}$ \\
\hline 6. & $\begin{array}{l}\text { Generate an initial cost estimate, a preliminary design and design } \\
\text { schedule for the project. }\end{array}$ & 13. Project Management \\
\hline
\end{tabular}




\begin{tabular}{|c|c|c|}
\hline 7. & $\begin{array}{l}\text { Apply principles of technical and professional communication in } \\
\text { preparing and organizing various written reports and oral presentations, } \\
\text { by effectively integrating verbal, written, virtual and graphical } \\
\text { information for the purpose of communicating observations and } \\
\text { solutions to technical and non-technical audiences. }\end{array}$ & 16. Communication \\
\hline
\end{tabular}

The pre-revision version of CE Project 1 required several deliverables:

Project Concept: A single-page "pre-proposal" submitted to the coordinator that included the project name, a list of the team members and a short project description. Its main purpose was to impel students to focus on forming teams and commence discussions on potential projects as early in the term as practicable.

Project Proposal: Submitted to the coordinator, and essentially an expansion of the Project Concept, the Proposal was a two-page document that more fully described the project and its location, stated team members' choices of civil engineering subdiscipline, and provided a preliminary timeline for task completion.

Progress Report: A team-based collaboration with written and oral components, the report is submitted to the team advisor and generally addresses the tasks each subdiscipline has accomplished in the project cycle.

Technical Report: An in-depth coverage of the work of each subdiscipline, submitted individually by students to their subdiscipline advisors.

The general timing for the pre-revision CE Project 1 deliverables is set forth in the graphic in Figure 1.

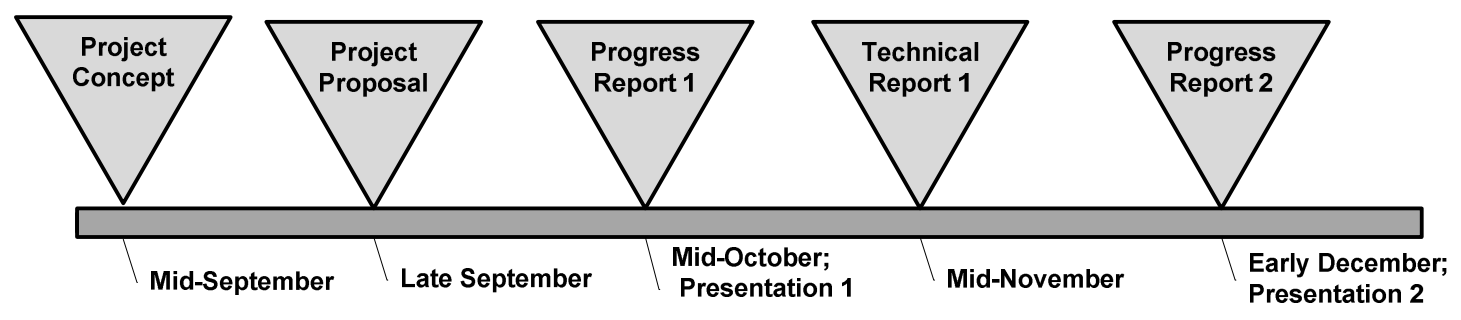

Figure 1 Pre-revision Deliverable Timeline for CE Project 1

\section{B. CE Project 2}

The overall goal for CE Project 2 is the continuation of the planning process, resulting in completed conceptual subdiscipline designs and a project management plan.

Some of the tasks students perform in CE Project 2 include:

- completing integrating all the subdiscipline designs; and

- completing project management tasks, including finalizing the schedule and cost estimates. 
Table 4 lists the course objectives for CE Project 2, along with their program outcome correlates.

Table 4: CE Project 2 Course Objectives

\begin{tabular}{|c|c|c|}
\hline NO. & OBJECTIVE & OUTCOMES \\
\hline 1. & $\begin{array}{l}\text { Use the knowledge and skills in civil engineering to conduct final } \\
\text { analyses and evaluations, and complete the designs of project } \\
\text { components, in order to master multiple portions of the technical breadth } \\
\text { and specialization outcomes required to function as competent civil } \\
\text { engineers. }\end{array}$ & $\begin{array}{l}\text { 3. Social Sciences } \\
\text { 5. Material Sciences } \\
\text { 6. Mechanics } \\
\text { 8. Problem Solving } \\
\text { 9. Design } \\
\text { 10. Sustainability } \\
\text { 14. Breadth } \\
\text { 15. Technical Specialization } \\
\text { 17. Public Policy } \\
\text { 21. Lifelong Learning }\end{array}$ \\
\hline 2. & $\begin{array}{l}\text { Integrate the designs of the various subdisciplines into the overall } \\
\text { comprehensive design, in accordance with project requirements and } \\
\text { industry standards. }\end{array}$ & $\begin{array}{l}\text { 3. Social Sciences } \\
\text { 8. Problem Solving } \\
\text { 9. Design } \\
\text { 17. Public Policy } \\
\text { 21. Lifelong Learning }\end{array}$ \\
\hline 3. & $\begin{array}{l}\text { Further develop and expand on the initial project management plan by } \\
\text { updating the schedule and cost plans, and adding appropriate subsidiary } \\
\text { plans, such as safety management, quality assurance, etc. }\end{array}$ & $\begin{array}{l}\text { 12. Risk \& Uncertainty } \\
\text { 13. Project Management } \\
\text { 17. Public Policy } \\
\text { 18. Business \& Public } \\
\text { Administration } \\
\text { 23. Lifelong Learning }\end{array}$ \\
\hline 4. & $\begin{array}{l}\text { Continue to develop effective team dynamics through frequent meetings } \\
\text { with open and considerate discussions until project completion. }\end{array}$ & $\begin{array}{l}\text { 20. Leadership } \\
\text { 21. Teamwork } \\
\text { 22. Attitudes }\end{array}$ \\
\hline 5. & $\begin{array}{l}\text { Apply principles of technical and professional communication in } \\
\text { preparing and organizing various written reports and oral presentations, } \\
\text { by effectively integrating verbal, written, virtual and graphical } \\
\text { information for the purpose of communicating observations and } \\
\text { solutions to technical and non-technical audiences. }\end{array}$ & 16. Communication \\
\hline
\end{tabular}

The technical report and progress report deliverables are essentially the same as in CE Project 1. The final report, similar to progress reports, is team-based and is comprised of written and oral components. The final report, however, is a complete record of all the work performed by each team, including final subdiscipline design and project management plan elements.

The general timing for the pre-revision CE Project 2 deliverables is set forth in the graphic in Figure 2.

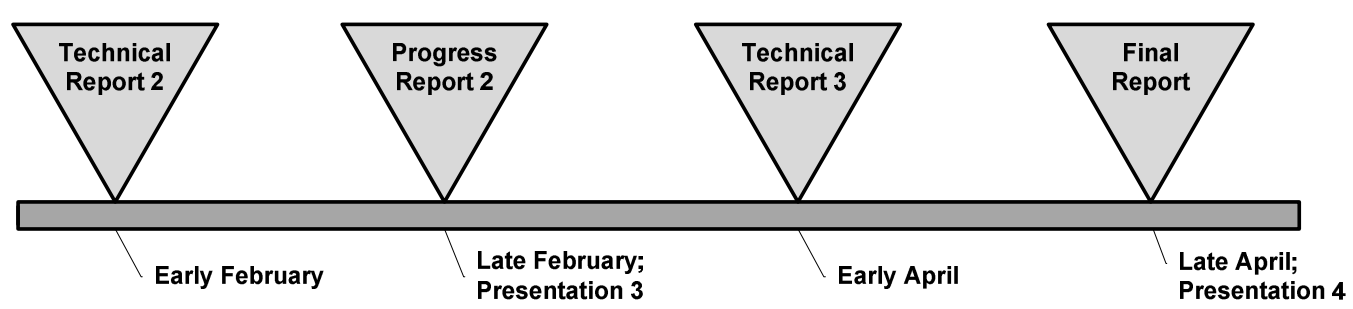

Figure 2: Pre-revision Deliverable Timeline for CE Project 2 


\section{C. Updating the Capstone Deliverables}

The first sentence in the Executive Summary in the BOK2 is: "The manner in which Civil Engineering is practiced must change." 11 Recognizing the need to positively change a process, a curriculum, or even a specific course, is the essence of continuous improvement. Mapping the BOK2 outcomes to the capstone sequence was an important first step, but faculty recognized the need to effect additional improvements.

Although there is always an academic aspect to every assignment in an engineering curriculum, faculty decided that there needed to be a better academia/real world balance in the capstone. Faculty agreed that one way to strike this balance would be to revise the course deliverables to more closely reflect actual project deliverables. Figure 3 is the revised deliverable timeline for CE Project 1.

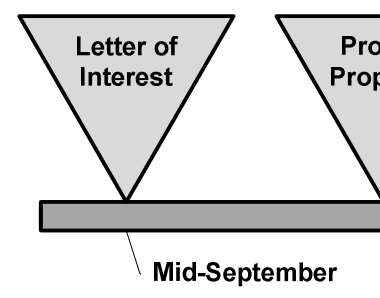

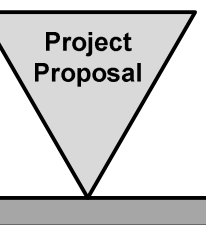

\begin{abstract}
Early/Mid October;
\end{abstract} Proposal Defense Presentation 1
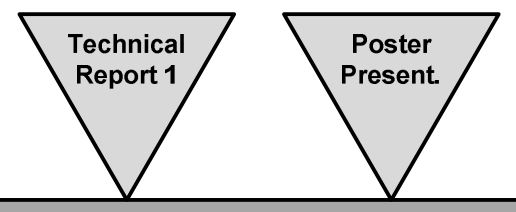

Mid-November (1)

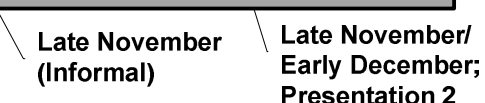

Presentation 2

Figure 3: Revised Deliverable Timeline for CE Project 1

The real world dictates that construction and engineering firms must demonstrate a customer focus. To incorporate this concept, faculty created the fictitious SeniorDesign Venture Capital Fund (Fund) to serve as the entity that would solicit project proposals for possible funding. The Fund disseminates a request for proposal that sets forth the minimum criteria for a project, including:

- Project scope

- Anticipated constraints

- Preliminary cost

- Sustainability and environmental issues

- Information on proposed location

Letter of Interest: The letter serves much the same purpose as the Project Concept document: eliciting general information on the proposed project, team composition, etc. The name of the document was changed to reflect the procedures utilized by project owners who seek to generate a short list of proposers.

Project Proposal: The pre-revision proposal was a relatively short document whose purpose was essentially to insure that students were moving forward with a project concept. Unlike in the industry when, for example, a design-builder submits a proposal for a new project, the student teams never formally proposed their projects. Faculty believed that rather than requiring two progress reports during the term, it was more realistic — and made more 
sense- - to replace the first progress report with a relatively in-depth proposal that had both a written and an oral component.

Technical Report: The technical report is the same as pre-revision; students report on their subdiscipline work product, whether it was design or project management based.

Poster Presentation (Informal): The most recent addition to the revised deliverables is the informal poster presentation during CE Project 1. This component was added in fall 2010 after the 2010 spring student focus group stated that the feedback received from the Advisory Board members during the poster presentation in CE Project 2 was especially valuable. And while the students appreciated the face-to-face contact with Advisory Board members, they also believed that such feedback would have been helpful had it occurred earlier in the project cycle.

Consequently, a poster presentation was added to CE Project 1 . Because the syllabus was already crowded with deliverables, faculty decided that the presentation would be informal; that is, Board members would not evaluate the posters, nor would the teams receive a grade. Rather, the members were asked to provide general feedback on such topics as the:

- quality and effectiveness of the posters;

- overall project concept; and

- proposed subdiscipline scope of work.

Progress Report: For the progress report in CE Project 1 there was no changes from prerevision requirements.

While CE Project 2 is officially a second course, the capstone sequence is viewed by the faculty and students as a continuum. As such, changes were also incorporated into the CE Project 2 deliverables (Figure 4) to build upon CE Project 1 experiences.

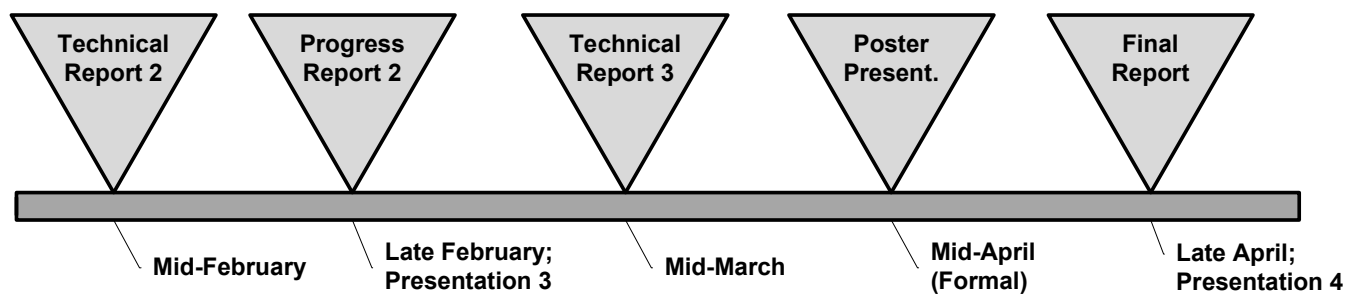

Figure 4: Revised Deliverable Timeline for CE Project 2

Technical Report: There were no changes to the technical report requirements.

Progress Report: The oral component of the progress report is the same as the pre-revision component. However, faculty determined that since the addition of the poster presentation (as discussed below) created another deliverable, an existing deliverable should be removed from the syllabus. It was decided that the deletion of the written component of the progress report, which was more or less a compilation of the various subdiscipline technical reports, 
would cause the least disruption to the capstone. Depending on the results of further discussions with faculty, the written component for Progress Report 1 in CE Project 1 may also be removed as a deliverable.

Poster Presentation: When initially implemented, the poster presentation was held in the afternoon, immediately preceding the final presentations. The assumption was that this approach would allow the Advisory Board to acquaint itself with the various projects and team members. Unfortunately, few Board members could arrive early, and there was insufficient time for the members to visit each poster or to meet all the teams. Moreover, similar to the final presentations, any comments or suggestions Board members made would not assist students with improving their projects.

Final Report: The requirements for this deliverable remain the same; students must make a final oral presentation and generate a written final report that summarizes all the work of the subdisciplines for the entire project cycle.

\section{Practitioner Involvement}

\section{A. Original Practitioner Participation}

Previous to academic year 2009-2010, practitioner participation in the capstone sequence was minimal. Indeed, the only involvement occurred on the final day; members of the Civil Engineering Advisory Board were traditionally invited to attend the final oral presentations to interview and evaluate the teams. Each team presents for fifteen minutes and the Board members are allotted fifteen minutes to ask questions and comment on the teams' work product.

The drawbacks to this format are immediately apparent. Since the Board members only review the projects at the final presentations, they have no opportunity to positively impact the students' work product. While this interaction may provide some educational nuggets for students to carry into their professional careers, it is certainly too late to incorporate any member comments into their capstone content.

Another drawback is that the final presentations are the first time students interact with "outsiders." All previous presentations were made to an audience comprised of faculty and the other project teams. In essence, teams must make their most important presentation to industry practitioners, without having any previous contact with them.

\section{B. Mentor Initiative}

One of the major impetuses for considering additional practitioner involvement was the Department's adoption of the BOK2. Although practitioner participation in undergraduate education is not is explicitly addressed in BOK2, it is arguably within the spirit of the document.

Faculty discussed at length the importance of additional practitioner involvement and determined that although the Advisory Board participation in the final oral presentation was highly beneficial, it was also insufficient from the perspective of both the students and the entire 
program. Consequently, faculty commenced the mentor initiative, which developed over the past two years, by adding several mentoring sessions to the capstone schedule.

Figure 5 graphically depicts the practitioner interaction in CE Project 1 by overlaying the mentor sessions onto the deliverables timetable.

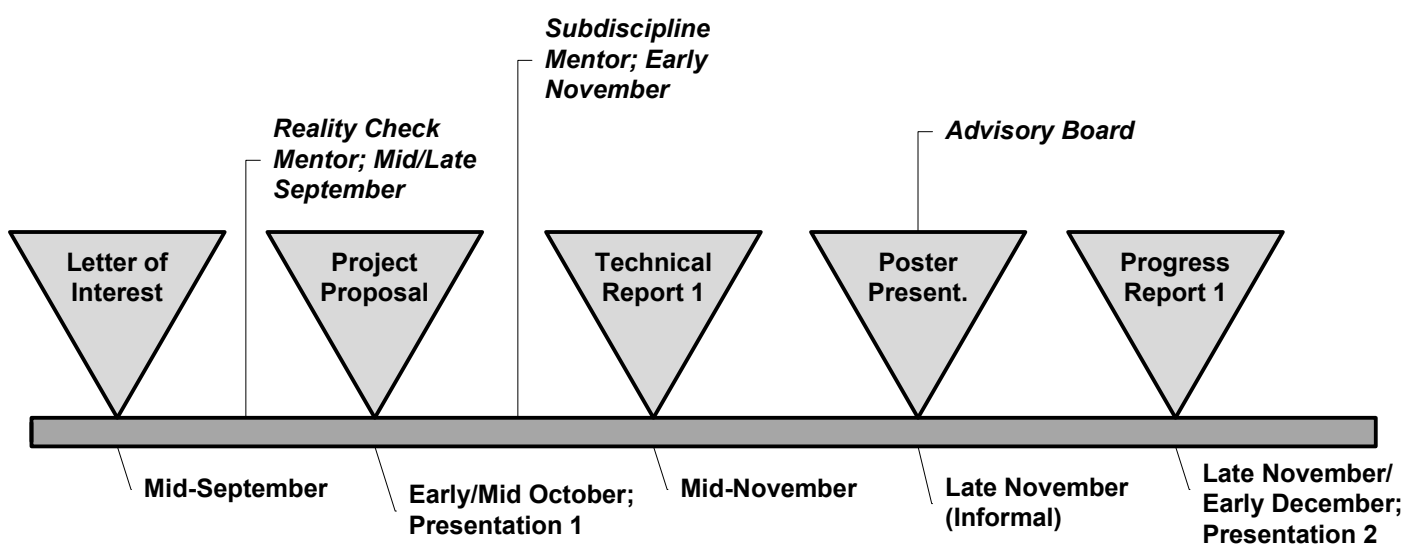

Figure 5: Deliverable/Practitioner Timeline for CE Project 1

Reality Check Mentor (RCM): The RCM component of the practitioner initiative was first introduced into CE Project 1 in fall 2009. The overall charge to the RCMs was to:

- serve as a sounding board for the teams on their initial thoughts and ideas on their proposed projects;

- play the devil's advocate by asking probing questions and encouraging teams to critically review and evaluate their choices; and

- provide professional expertise and perspective on team questions regarding general design and project management approaches.

For the fall 2009 term, mentors were chosen from the Advisory Board roster, without regard to professional experience or civil engineering subdiscipline. Faculty assumed that Board members would possess sufficient general project knowledge to provide teams with appropriate feedback. Based on remarks by a student focus group after completion of the 2009-2010 capstone, however, it became evident that mentors whose background were in a specific subdiscipline, such as structures or water resources, were unable to provide substantive feedback on overall project viability.

To address this situation, in the 2010-2011 capstone sequence RCMs were vetted and chosen more carefully. Only those that possessed overall project experience, such as design-builders and developers, were asked to participate. Additionally, faculty attempted to match the mentor's professional expertise with a team's proposed project. For example, one proposed capstone project entailed a parking deck with classrooms and offices on the top floor. For the RCM, faculty solicited a consultant who had extensive experience designing and constructing parking structures throughout the United States. 
Faculty believed that as a way to make the interaction more professional, teams should meet the RCMs at their place of business. Not only did most mentors host teams at their offices, several invited additional employees to participate and contribute, making the experience even more realistic and rewarding.

Subdiscipline Industry Mentor (SIM): When faculty initially began considering whether to involve industry practitioners, there was much discussion about whether they were needed, especially when addressing specific subdisciplines. Theoretically, faculty should possess sufficient leading-edge expertise to handle any student questions.

Ultimately, faculty determined that another set of eyes reviewing a design or project management plan was a positive approach to take. Moreover, from a continuous improvement point of view, receiving feedback from practitioners on capstone and specific course content would raise the level of competence of the entire program.

\section{Poster Presentation (Informal):}

As discussed above, in response to student's positive reaction to the poster presentation in CE Project 2, a poster session was added to CE Project 1 . The presentation was scheduled for the late afternoon of the fall Advisory Board evening meeting.

Board members often remark that they would like to acquaint themselves with the projects earlier in the cycle, preferably prior to final presentations. The informal session served this purpose well. But another reason for a poster presentation became apparent: it was obvious the Board members thoroughly enjoyed sharing their expertise, talking design, discussing construction techniques, etc., with soon-to-be engineers.

Figure 6 graphically depicts the practitioner interaction in CE Project 2 by overlaying the mentor sessions onto the deliverables timetable.

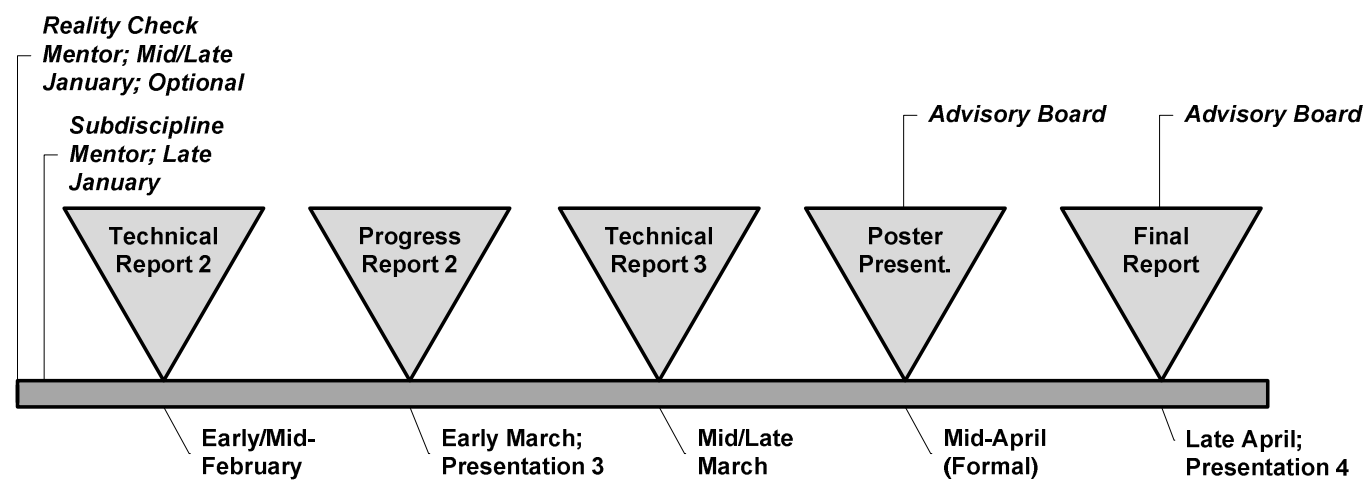

Figure 6 Deliverable/Practitioner Timeline for CE Project 2

Reality Check Mentor: In the 2009-2010 capstone sequence, teams met with their RCMs only in the fall. Faculty believed that requiring a formal meeting in the spring term might place too 
much additional pressure on the students, who already had to deal with a crowded syllabus, as well as all the other issues in their final semester: the FE exam, resume preparation and interviewing for jobs, and, probably worst of all, senioritis.

Surprisingly, several RCMs contacted faculty to inquire as to how their mentee teams were progressing, demonstrating genuine interest in the projects and the students' welfare.

In response, for CE Project 2 in spring 2011, an optional meeting with the RCM was included in the syllabus. Students could earn 5\% extra credit if their team met with their RCM.

Subdiscipline Industry Mentor: The interaction with the SIM is the same as in CE Project 1. Faculty assumes the students have progressed with their subdiscipline designs and project management plans, and thus the interactions with the mentors should result in refinement of their work product.

Formal Poster Presentation: The formal poster presentation was added as a deliverable in spring 2009. The session is scheduled for the late afternoon prior to an Advisory Board meeting, thereby allowing a significant number of Board members to participate. The project teams are located in one room and each exhibits a professionally printed poster that addresses all the teams' subdisciplines. Although students are provided a table for any plans and other documents they may have generated in the process, only the quality of the poster and the students' oral skills are evaluated.

Final Report: No changes were made to the final report components. Faculty grades the written report, and the Advisory Board grades the oral presentation.

\section{C. Assessment of Practitioner Involvement}

An online student survey was conducted in December 2010, at the end of the CE Project 1 course, to elicit student perceptions on the value of the mentor initiative. Twenty-seven of the thirty-one students responded to the survey, and they were asked the same set of five questions for each of the three practitioner sessions (Reality Check Mentor, Subdiscipline Mentor, and Poster Session). The first two questions were based on a five-point Likert scale that ranged from "Strongly disagree" to "Strongly agree:"

1. The mentor provided my team with comments and ideas that assisted in our understanding of the project requirements.

2. The mentor provided my team with comments and ideas that assisted in our research of the project requirements and other project issues.

The next two questions were of the open-ended essay variety that allows the students the opportunity to discuss their thoughts on the sessions.

3. Describe the most useful aspect of the meeting. 
4. What so you think could have made the meeting more useful?

The final question required a simple yes/no answer, seeking to determine if students thought the sessions were useful enough to repeat in CE Project 2:

5. If you had a choice, would you choose to meet with your mentor during the second term of the capstone to update him/her on your team's (or your individual) progress?

For the Reality Check Mentor (RCM) Session, the first two questions demonstrated an overwhelmingly positive experience with $88 \%$ of the students agreeing that the RCM assisted the team with understanding project requirements (Figure 7). Furthermore, 96\% agreed that the RCM guided their research process (Figure 8). Finally, $88 \%$ of students indicated that they wanted to meet with their RCM in CE Project 2.

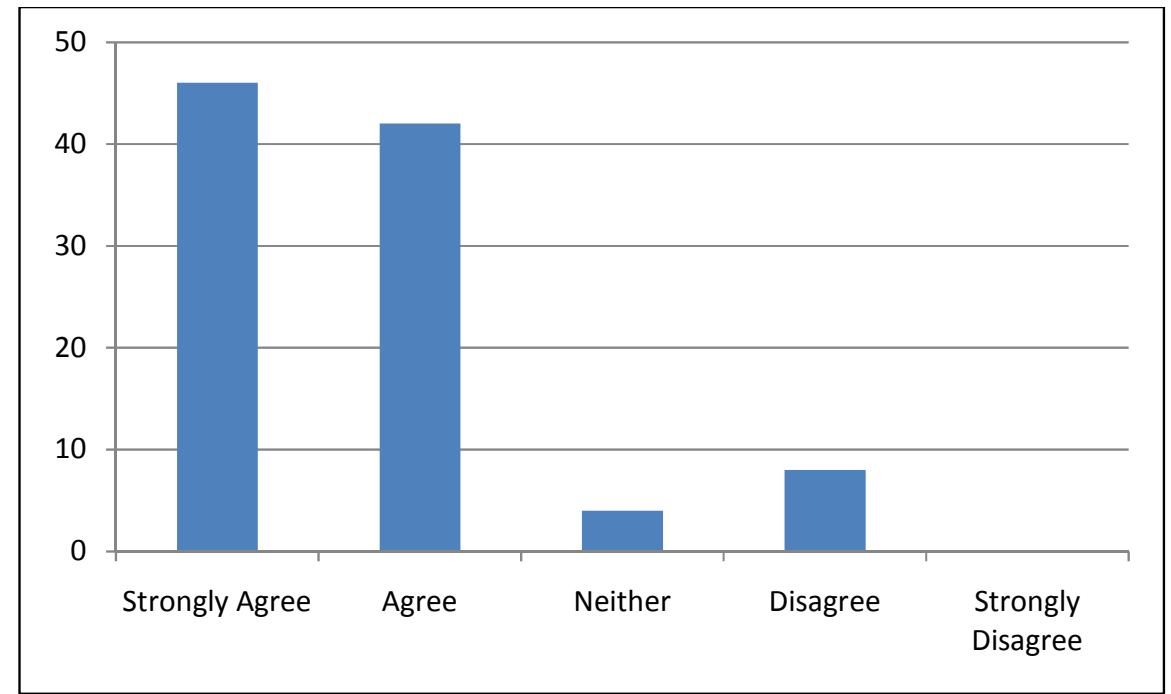

Figure 7: Student responses to "RCM assisted with my team's understanding the project requirements." 


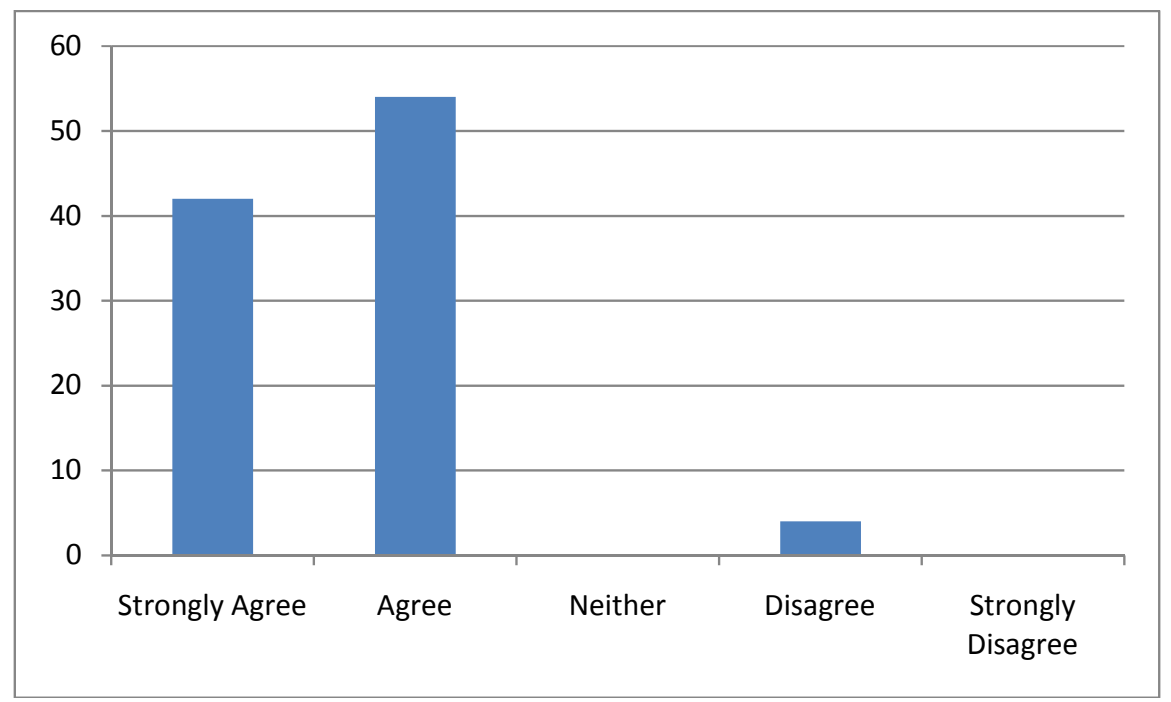

Figure 8: Student responses to "RCM assisted with my team's research."

Student responses to the open-ended question on the usefulness of the RCM session centered on two main themes: providing avenues for research and making the projects more realistic, as the sample student responses below suggest:

- ...helped determine what was feasible...

- ...gave us many ideas which we had not previously considered...

- ...discussed whether our ideas were realistic...

- ...provided initial ideas on refining the project...

- ...gave practical feedback...

Two themes also dominated the responses to the question on how to make the session more useful. The early timing of the session was a concern to many of the students. Moreover, several commented on whether the mentors should have been provided with more upfront information:

- ...it would have been better if we had a better understanding of our own project...

- ...we were still uncertain as to what our project would be ...

- ...it would have been more useful if we understood the scope of our project before the meeting...

- ...give the mentors a better concept as to what the capstone is about...

- ...help the mentors understand the goals of the course and the differences between academic and practical designs ahead of time...

When compared with the RCM results, the Subdiscipline Mentor session was not as positively received. $67 \%$ of the students agreed that the Subdiscipline Mentor assisted the team with understanding project requirements (Figure 9), with a slightly larger number of respondents$71 \%$ - agreeing that the mentor provided guidance for their research process (Figure 10). For the last question, $71 \%$ of students indicated that they wanted to meet with their Subdiscipline Mentor 
in CE Design 2, suggesting that those that did not find the initial session helpful, did not consider the possible value of later sessions.

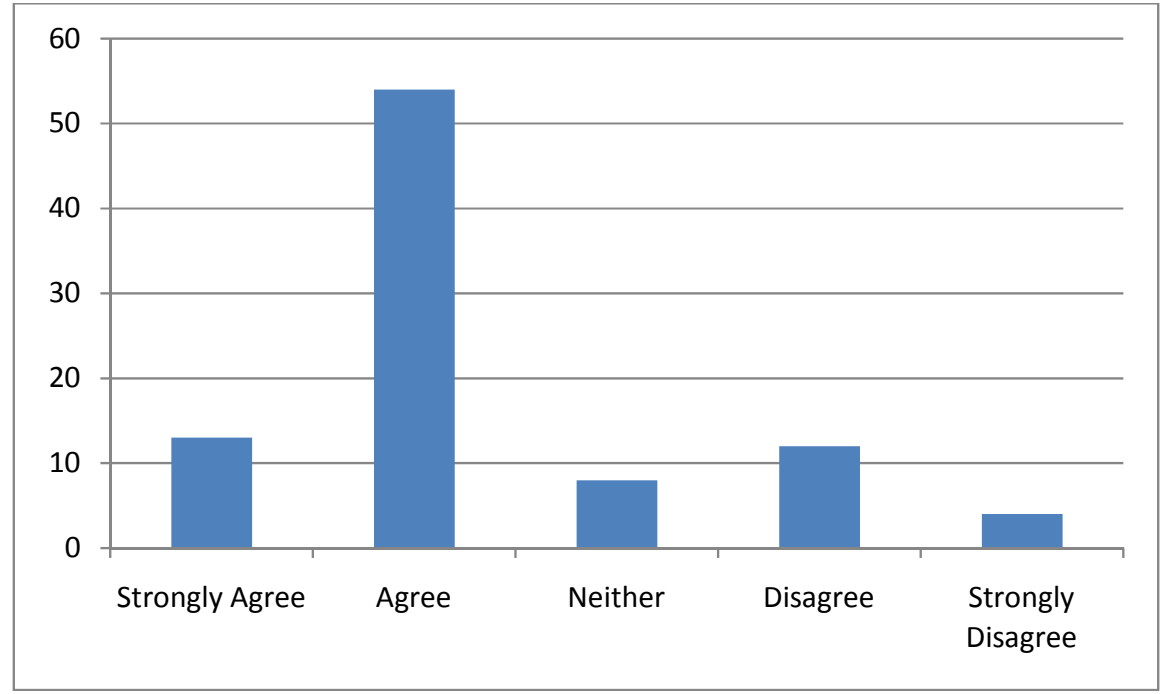

Figure 9: Student responses to "Subdiscipline Mentor assisted with my understanding the project requirements."

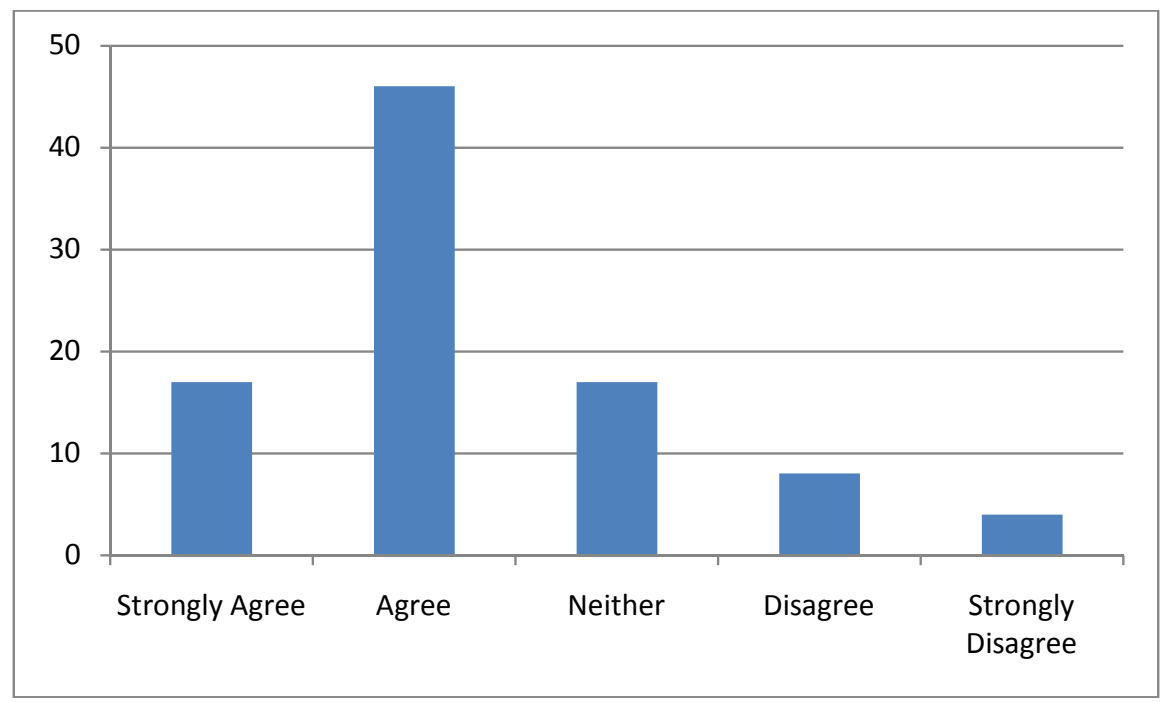

Figure 10: Student responses to "Subdiscipline Mentor assisted with my research."

Not surprisingly, the Subdiscipline Mentor session was most useful for the assistance it provided the students with, research opportunities, scope issues and evaluation of alternatives:

- ...assisted with specific design approaches...

- ...helped me narrow down my design alternatives ...

- ...I was able to define my scope of work... 
- ...discussed assumptions and real-world designs...

- ...how to focus on research...

To improve the Subdiscipline Mentor session, there was one overarching observation:

- ...we needed more time with the mentor...

- ...the meeting was too short...

- ...more time, and possible a second mentor to bounce ideas off of...

- ...more time-I think the mentor would have stayed much longer...

The results for the informal poster session were similar to the Subdiscipline Mentor session. $67 \%$ of the respondents thought the Advisory Board members assisted the team with understanding project requirements (Figure 11), and a tepid 63\% agreed that the members assisted with their research (Figure 12).

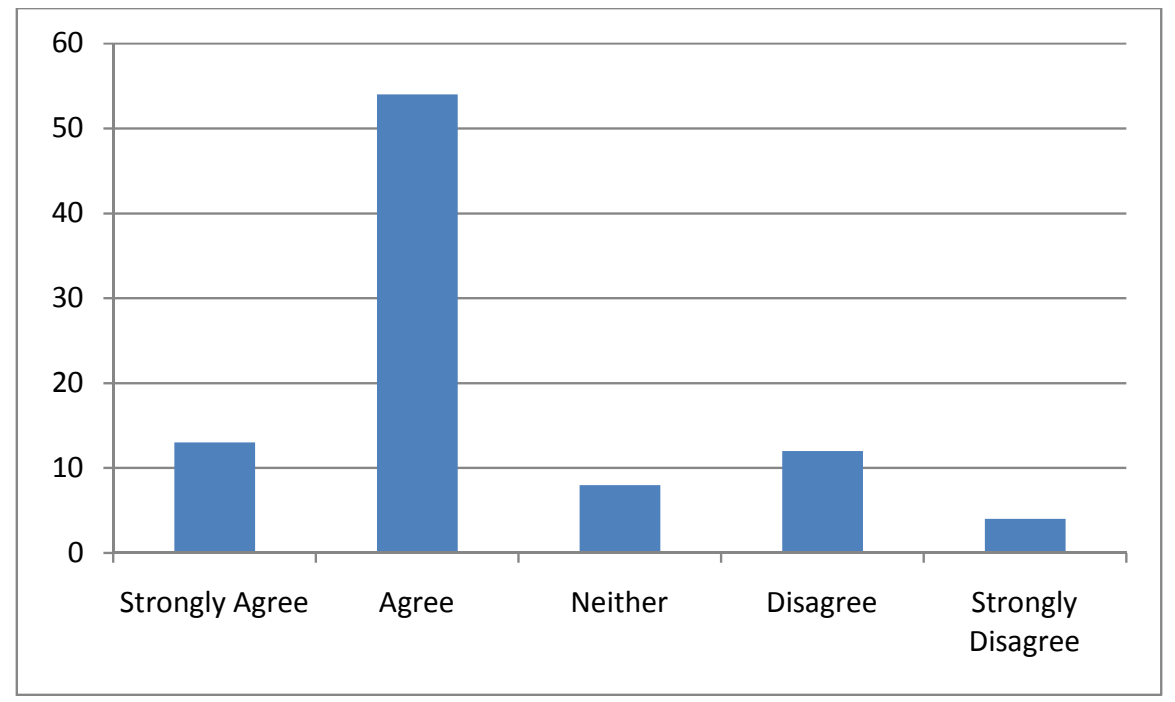

Figure 11: Student responses to “Advisory Board members assisted with my team's understanding the project requirements." 


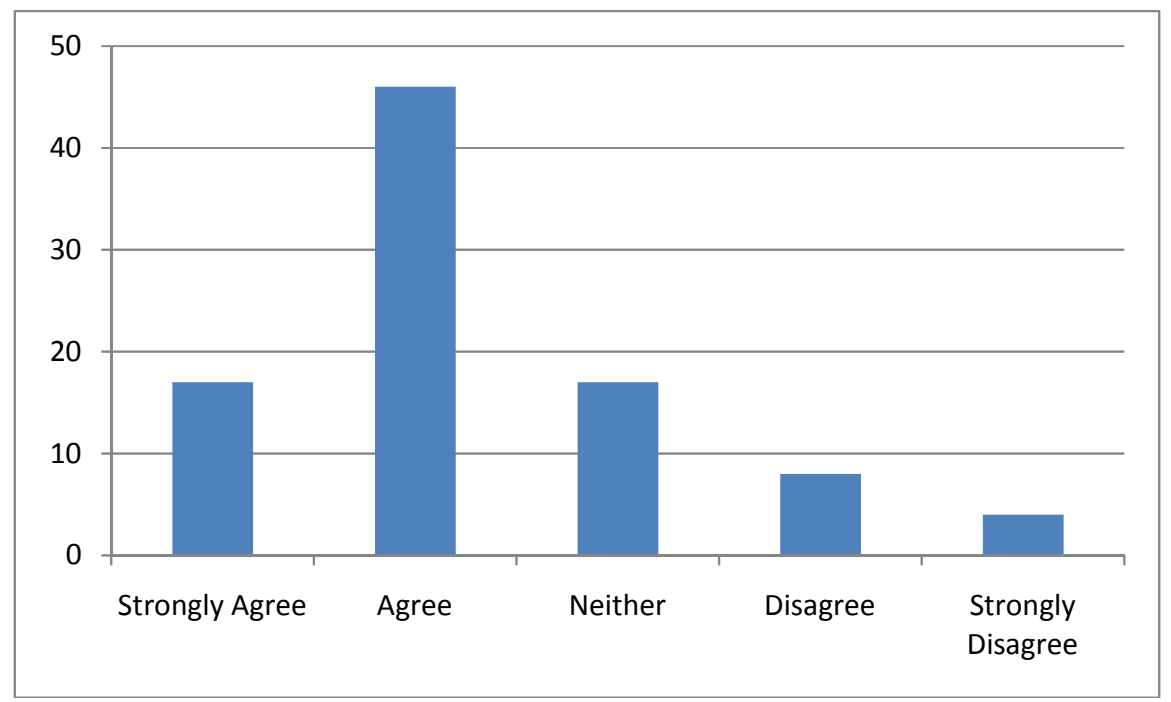

Figure 12: Student responses to "RCM assisted with my team's research."

When asked about the most useful aspect of the informal poster session, the students' comments generally focused on the opportunity to interact with industry practitioners, and the feedback provided by the Board members on their projects:

- ...gave us perfect ideas to improve our project...

- ...hearing the feedback and ideas of industry insiders...

- ...seeing what the client is really looking for...

- ....allowed us to meet the Board in a slightly less scary way...

- ...great networking opportunity...

The relatively tepid approval of the poster session is punctuated by the students' responses to the question what could make the session more useful, which implied that the faculty should have done a better job preparing the Advisory Board members:

- ...the Board should be better informed on the purpose of the session...

- ...it seemed that several Board members did not understand the scope of the course...

- ...The Board should have a better understanding of the project requirements...

While the percentages suggest that the mentor sessions were a success, improvements are clearly needed. First and foremost, the mentors should be given additional background information on the course requirements and the various projects. This is especially true with respect to the Subdiscipline Mentor and informal poster sessions. It is anticipated that faculty will conduct another survey at the end of CE Project 2; the results should demonstrate whether students' positive perception of the mentor interaction grows from that in CE Project 1.

During informal discussions with various mentors, they made it clear that they enjoyed the sessions and the interaction with the students. Moreover, all the mentors would consider 
participating in future sessions. Indeed, several expressed interest in viewing the final oral presentations at the conclusion of CE Project 2.

\section{Final Comments}

When initially discussing the involvement of the Civil Engineering Advisory Board and other practicing engineers, faculty believed that it would generally be a positive experience. For example, from the perspective of the students, the practitioners provided additional breadth and depth to the various subdisciplines, as well as the overall projects. With due respect to the faculty, it was evident that students should experience different voices from the industry. Moreover, practitioner involvement directly addresses two of the technical outcomes from the BOK2: \#14 Breadth in Civil Engineering Areas and \#15 Technical Specialization.

Of course, there are those students that found the mentor sessions little more than another hoop to jump through. A challenge for future courses is to convince all the students that the sessions are indeed of great importance, and should be taken advantage of.

There is no question that there were challenges with engaging practitioners. Vetting and coordinating the mentors was admittedly time-consuming and, at times, problematic. For example, in a few instances practitioners were compelled to cancel at the last moment due to business or personal reasons. Sometimes they were able to provide a substitute; other times, however, faculty scrambled to fill the slot. Furthermore, even when they were briefed on the course and mentor requirements, some mentors still did not fully understand their role.

The student survey demonstrated that the Reality Check Mentor sessions were the most useful to the students. But what also became clear from the survey, as well as informal discussions with students and mentors, was that the more prepared everyone is for a particular session, the more likely the participants will consider the session a success. This is especially true for the Subdiscipline Mentor and the poster sessions. It is believed, however, that lack of preparation will become less of an issue as Advisory Board members and other industry practitioners participate in more sessions.

Although it was not part of the initial discussions when faculty was deciding whether to embark on the mentor initiative, the sessions were valuable with respect to future relationships. The students had the opportunity to demonstrate their abilities to potential employers. On the other hand, employers could watch students perform in a forum that is unlikely to be duplicated in an interview setting. 
References

1. Quagliana, C., Russell, J., Doran, M., Hassett, R., and Harrington G. (2010) "University of Wisconsin-Madision Civil \& Environmental Engineering Capstone Design Class. A Class in Constant Redesign and Improvement," Proceeding of the 2010 ASEE Conference and Exhibition.

2. Fries, R., Cross, B., and Morgan, S. (2010) "An Innovative Senior Capstone Design Course Integrating External Internships, In-Class Meetings, and Outcome Assessment," Proceeding of the 2010 ASEE Conference and Exhibition.

3. Ingalsbe, D. and Godbey, J. (2005) "Project Oriented Capstone Course: Integrating Curriculum Assessment Utilizing Industry Partner and Student Input," Proceeding of the 2005 ASEE Conference and Exhibition.

4. McGinnis, M. and Welch, R. (2010) "Capstones with an Industry Model," Proceeding of the 2010 ASEE Conference and Exhibition.

5. Fiegel, G., and DeNatale, J. (2010) "Collaborating with Local Practitioners to Lead a Capstone Civil Engineering Design Course," Proceeding of the 2010 ASEE Conference and Exhibition.

6. Akili, W. (2007) "A Practioner-Faculty Collaboration in Teaching Senior Design," Proceeding of the 2007 ASEE Conference and Exhibition.

7. Brunell, L.R. (2005) "Effective Implementation of Industry Sponsored Senior Design at Stevens Institute of Technology," Proceeding of the 2005 ASEE Conference and Exhibition.

8. Larson, D., and Hewes, J. (2010) "A Possible BOK2 Civil Engineering Curriculum," Proceeding of the 2010 ASEE Conference and Exhibition.

9. Gunnick, B. (2010) "How the Civil Engineering BOK2 Can Be Implemented at Montana State University," Proceeding of the 2010 ASEE Conference and Exhibition.

10. Friedley, K. (2010) "How the Civil Engineering BOK2 Can Be Implemented at the University of Alabama," Proceeding of the 2010 ASEE Conference and Exhibition.

11. Body of Knowledge Committee of the Committee on Academic Prerequisites for Professional Practice (2008) Civil Engineering Body of Knowledge for the $21^{\text {st }}$ Century, Second Edition, American Society of Civil Engineers, Reston, VA.

12. Anderson, R., Walesh, S., and Friedley, K. (2008) "The New and Improved Civil Engineering Body of Knowledge"

13. Anderson, L. and Krathwohl, D. (2001) A Taxonomy for Learning, Teaching, and Assessing. A Revision of Bloom's Taxonomy of Educational Objectives. Addison, Wesley, Longman, NY, NY.

14. Fridley, K.J., Hall, K. Sutterer, K. Larson, Larson, D., Alleman J., McManis, K., Bardet, J.P., Gunnick, B., List, G., Smith, R., and T. Lenox (2009) "Educating the Future Civil Engineering for the New Civil Engineering Body of Knowledge," Proceeding of the 2009 ASEE Annual Conference.

Appendices 